\title{
GLYCOPEPTIDES FROM CHITIN
}

\author{
L. Yu. Odinokova and N. V. Molodtsov
}

UDC 547.99512

Chitin is the main component of the complex of the external skeleton of insects and crustaceans. This complex contains protein, lipids, pigments, and a peculiar polysaccharide - chitin - cemented by calcium carbonate. Recently, in the literature, reports have appeared in which the authors suggest that chitin is linked with polypeptides by a covalent bond $[1,2]$. However, as yet there have been no strict proofs of the existence of covalent bonds, nor have glycopeptide fragments been isolated from chitin.

To obtain glycopeptide fragments from chitin, we used its severe fragmentation under the action of concentrated strong mineral acids which, at low temperature, preferentially cleave glycosidic bonds rather than peptide bonds. On subsequent ion-exchange chromatography of the hydrolyzate, a number of glycopeptides containing amino acids and amino sugars were isolated. From thei $r$ behavior in ch romatog raphy on DEAE-cellulose and on gel filtration, the fragments correspond to polypeptides and amino sugars covalently bound to one another. We assume that in these compounds the presence of $\mathrm{N}$-aminoacyl derivatives of glucosamine is possible, these representing the nodal points of the bonds between the polysaccharide and polypeptide components of the chitin. This is also shown by the fairly high content of protein and the high molecular weight of chitin (determined after its conversion into chitosan) in the shell of the crab.

Chitin was obtained from the shell of the Kamchatka crab by its decalcification with $1 \mathrm{~N} \mathrm{HCl}$ and ethylenediaminetetraacetic acid. The lipids and pigments were eliminated with organic solvents. The chitin powder $(10 \mathrm{~g})$ was moistened with $20 \mathrm{ml}$ of water and was treated at $0^{\circ} \mathrm{C}$ with $75 \mathrm{ml}$ of concentrated $\mathrm{H}_{2} \mathrm{SO}_{4}$. The hydrolyzate was kept at $50^{\circ} \mathrm{C}$ for $24 \mathrm{~h}$ and was then precipitated with 0.5 liter of $\mathrm{n}_{-} \mathrm{C}_{3} \mathrm{H}_{7} \mathrm{OH}$ and two liters of ether. The precipitate was dissolved in water and neutralized with $\mathrm{BaCO}_{3}$, and the filtrate was chromatographed on a column of DEAE-cellulose, being eluted first with water and then with a concentration gradient of $\mathrm{NaCl}$. The amounts of proteins and amino sugars were determined in the fractions after hydrolysis by the Elson-Morgan reaction. Fractions containing proteln and amino sugar corresponding to the individual peaks were combined, evaporated in vacuum, and desalted on Sephadex G-10. After rechromatography on DEAE-cellulose and desalting, the corresponding fractions were freeze-dried.

\section{TE RA TURE CITED}

1. H. Lipke, Insect Biochem., 1,189 (1971).

2. H. Lipke and T. Geoghegan, Biochem. J., 125, 703 (1971).

Pacific Ocean Institute of Bioorganic Chemistry of the Far-Eastern Center, Academy of Sciences of the USSR. Translated from Khimiya Pri rodnykh Soedinenii, No. 1, pp. 118-119, January-Februa ry, 1974. Original article submitted March 20, 1973.

(O) 1975 Plenum Publishing Corporation, 227 West 17th Street, New York, N. Y. 10011. No part of this publication may be reproduced, stored in a retrieval system, or transmitted, in any form or by any means, electronic, mechanical, photocopying, microfilming, recording or otherwise, without written permission of the publisher. A copy of this article is avallable from the publisher for $\$ 15.00$. 